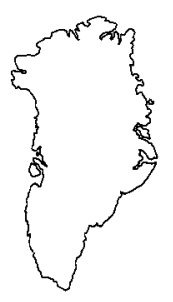

\title{
Resources of the sedimentary basins of North and East Greenland - an integrated petroleum and ore geological research project
}

\author{
Lars Stemmerik, Sven M. Jensen, John Korstgård, Hans K. Schфnwandt, \\ Finn Surlyk, Ole R. Clausen, Henrik Fougt, Karsten Kragh, \\ Bjarne R. Langdahl and Jens Therkelsen
}

A multidisciplinary research project 'Resources of the sedimentary basins of North and East Greenland' was initiated in 1995 with financial support from the Danish Research Councils. This is a joint project involving the Geological Survey of Denmark and Greenland (GEUS), the Geological Institute of the University of Copenhagen, the Department of Earth Sciences of the University of Aarhus and the Danish Environmental Research Institute (DMU). The participants include staff members of the institutes, four Ph.D. students and three post-doctorate stipendiates. The project is divided into three parts that all relate to exploration and exploitation of minerals and hydrocarbons in the sedimentary basins of North and East Greenland (Fig. 1).

The purpose of the hydrocarbon related studies is to develop models for petroleum systems in the three different types of sedimentary basins outcropping along the margins of North and East Greenland; the three selected basins are of different age, tectonic style and lithology. Furthermore, these results will be used in studies of the sedimentary basins offshore East Greenland. It is hoped that key elements from the specific models can be extracted to formulate general models that will aid the basic understanding of petroleum systems of similar basins world-wide. The selected basins are: the Lower Palaeozoic Franklinian Basin of North Greenland, the Upper Palaeozoic to Tertiary strike-slip dominated Wandel Sea Basin of eastern North Greenland, and the series of Upper Palaeozoic to Tertiary rift basins of East Greenland (Fig. 1).

The objectives of the ore-related studies are to increase the knowledge of stratabound mineralisation processes by integrating textural analysis, fluid inclusion analysis and stable isotope studies with hydrocarbon-related research methods, including sedimentology, sequence stratigraphy and hydrocarbon geochemistry. The primary focus of research is the Citronen Fjord zinc deposit in the Franklinian Basin of North Greenland (Fig. 2), with the aim of establishing a model describing the lead isotope signatures of specific stratigraphical units and potential metal source rocks. The knowledge gained from these studies will subsequently be applied to the metal sulphide-bearing Upper Permian
Ravnefjeld Formation of the East Greenland rift basins.

Environmental monitoring of mineral resources exploitation in the Arctic regions requires understanding of natural element dispersion mechanisms and patterns, and of the interrelationship between the biosphere and the rocks exposed to meteoric processes by any mining activity (see e.g. Steenfelt, this report). The role of biochemical cycles in stabilising or destabilising heavy metal sulphides in the meteoric environment will be studied in the Citronen Fjord area. This detailed study will be supplemented with biological baseline studies in order to identify areas that are environmentally sensitive to hydrocarbon and mineral exploration and exploitation.

During the 1995 field season, work was carried out in the Franklinian Basin of North Greenland and in the East Greenland rift basins. The investigations focused on ore geology and biochemistry in North Greenland and on structural geology, sedimentology and diagenesis in East Greenland. Additional fieldwork and studies of the petroleum systems in the Wandel Sea Basin of eastern North Greenland and the area around Kangerlussuaq in the southernmost of the East Greenland rift basins was carried out as part of investigations coordinated by GEUS and the Danish Lithosphere Centre, respectively (see Henriksen, this report; Larsen et al., this report).

\section{North Greenland}

Ore geological and microbiological field work was carried out in two areas of North Greenland in 1995, supported logistically from the Survey base in eastern North Greenland (Henriksen, this report) and with additional helicopter support from Platinova A/S. A two-man team (later in the field season a three-man team) worked out of field camps in the Navarana Fjord area and the Citronen Fjord area (Fig. 1).

The regional studies focused on the numerous minor pyrite, galena and sphalerite occurrences that occur in a narrow belt of Cambrian-Ordovician outer shelf and slope sediments between the north coast of Nyeboe Land and Navarana Fjord (Figs 1,2). The field relationships of the 


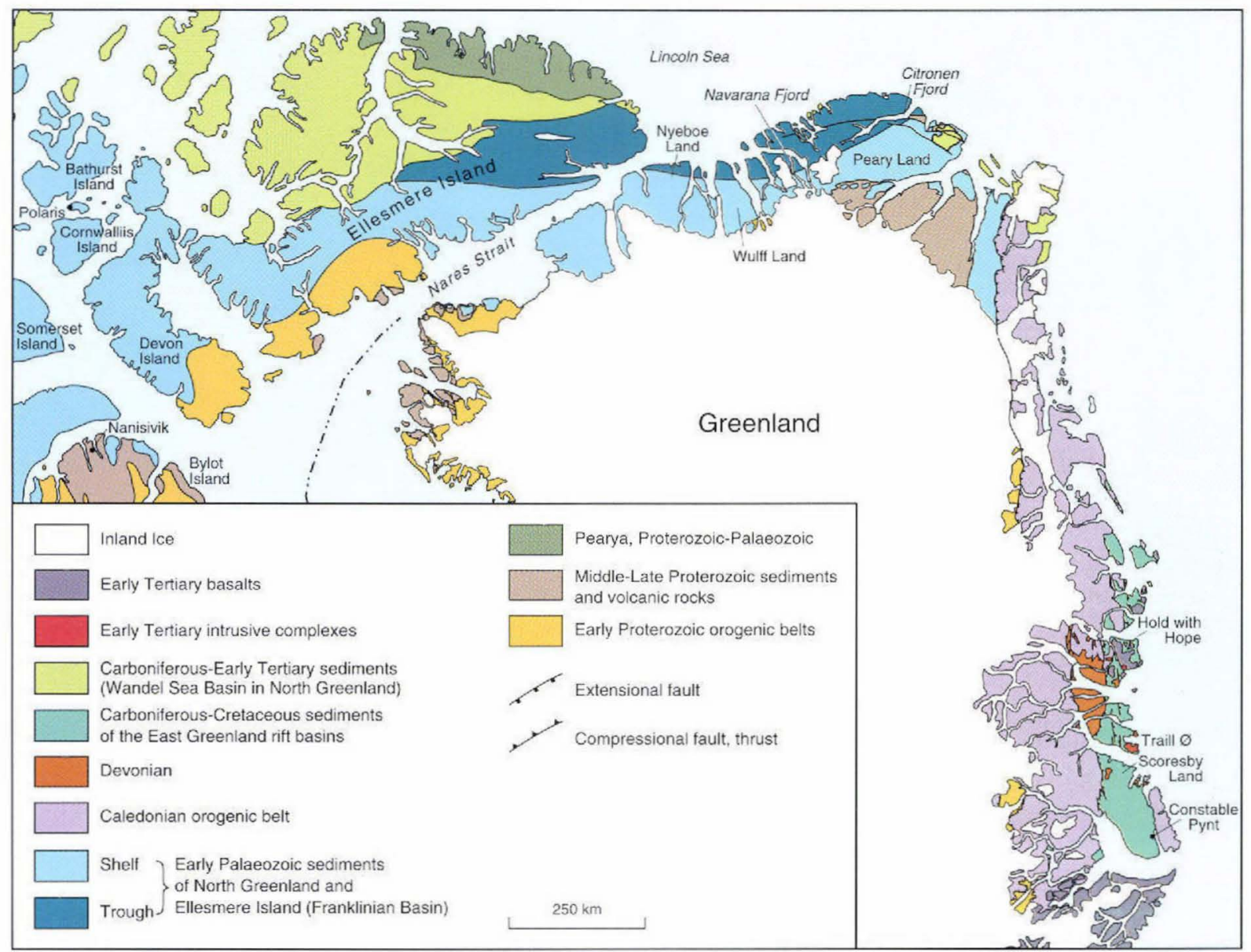

Fig. 1. Geological map of northern and eastern Greenland and eastern Canada showing outline of investigated basins.

sulphide mineralisations were investigated and collections made for ore petrographic studies, lead and stable (primary sulphur) isotopic analyses and fluid inclusion studies.

The Citronen Fjord zinc deposit is by far the largest mineral occurrence known in North Greenland. It is a stratiform, shale-hosted sedimentary exhalative (SEDEX) deposit within shales and cherts of the Upper Ordovician - Lower Silurian Amundsen Land Group (Higgins et al., 1991). The host sediments were deposited on a sediment-starved continental slope separated from a wide carbonate platform to the south by the prominent Navarana Fjord escarpment. The ore-bearing sediments are laminated mudstones interbedded with turbiditic sandstones and two major carbonate debris flow units of the Citronens Fjord Member (Hurst \& Surlyk, 1982). The ore has a simple mineralogy that includes pyrite, carbonates, sphalerite and galena. Spectacular primary and diagenetic textures are well preserved within the deposit. The primary textures are comparable with textures found in recently precipitated sulphide mounds on the seafloor, e.g. the Juan de Fuca Ridge in the Pacific Ocean (Paradis et al., 1988). Preliminary data from the Citronen Fjord deposit indicate that the mineralised zones form discrete mounds composed of semimassive to massive sulphide and carbonate intergrowths. The general textural element comprises different types of sulphide spheres including framboids, radiating spheres with complex intergrowths of pyrite, sphalerite, galena and carbonate, and massive spheres with small spheroidal inclusions of carbonate. Well-laminated sulphides interbedded with mudstone occur on the flanks of the sulphide mounds. The sulphide laminae consist of framboidal pyrite with interstitial carbonate and sphalerite (Fig. 3). In places secondary pyrite has overgrown the framboids, and later carbonates have partly replaced the pyrite. A description and interpretation of these textures form the main contribution to this part of the project.

A newly developed numerical, lithogeochemical methodology for recognition and quantification of alterations associated with hydrothermal mineralisations has been tested on a variety of large sediment-hosted massive sul- 


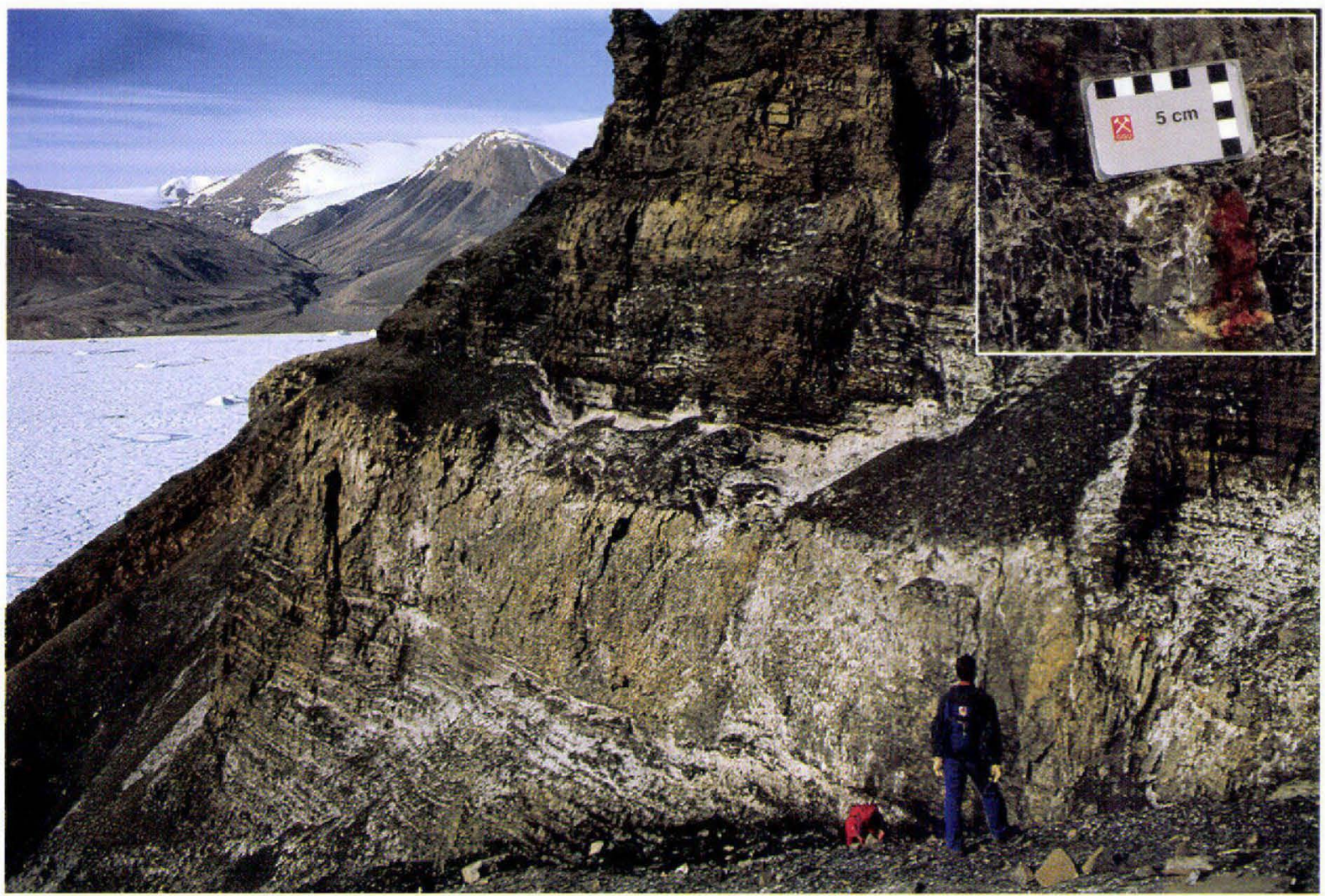

Fig. 2. Zinc-mineralised carbonate debris flow, top of Aftenstjernesø Formation, eastern Navarana Fjord. In the field, minor amounts of sphalerite can be detected indirectly by the presence of oxidation products (red-stained in insert photo),

phide deposits by C. R. Stanley, Mineral Deposit Research Unit (MDRU), University of British Columbia. The lithogeochemical approach will be tested on the Citronen Fjord deposit, in collaboration with MDRU, using samples collected in 1995. The methodology employs a combination of molar ratio diagrams, linear algebra and X-ray diffraction to constrain a 'background' model for the compositional variability of the unaltered sedimentary succession. Deviations from this model then indicate the nature and degree of hydrothermal alteration.

\section{Microbiological studies}

In order to test the role bacteria might play in forming the giant gossans developed on the massive sulphides outcropping in the Citronen Fjord area (see Schønwandt, 1994) surface material and water from streams draining the gossans were collected and analysed at the Department of Microbial Ecology, University of Aarhus. Provisional results show the presence of sulphide-oxidising bacteria and a previously undescribed acid-tolerant yeast strain (Langdahl, 1995). These results encourage further studies of the microorganisms and the microbial sulphide oxidation processes that form the very low-pH drainage below the gossans. The 'natural heavy metal pollution' in the Citronen Fjord area will be an important reference standard for future investigations concerning the effect of mining activities on microbial processes in similar environments in the high Arctic.

\section{East Greenland}

In central East Greenland field work was carried out in central and eastern Traill $\varnothing$ by two two-man teams supported by a helicopter based at Constable Pynt (Fig. 1). One team made structural studies of the post-Caledonian sediments, and the other studies of the Middle Jurassic sandstones. The area around Svinhufvud Bjerge is dominated by Lower Triassic reddish-grey sandstones and shales, Middle Jurassic yellowish sandstones, and dark grey Lower Cretaceous shales. An erosional remnant of Upper Jurassic shales of the Bernbjerg Formation conformably overlies the Middle Jurassic sandstones in the eastern part of Svinhufvud Bjerge. The Jurassic - Cretaceous boundary is an erosional and angular unconformity (Fig. 4). All sediments are intruded by early Tertiary basic sills and dykes, which often control the present topography. 


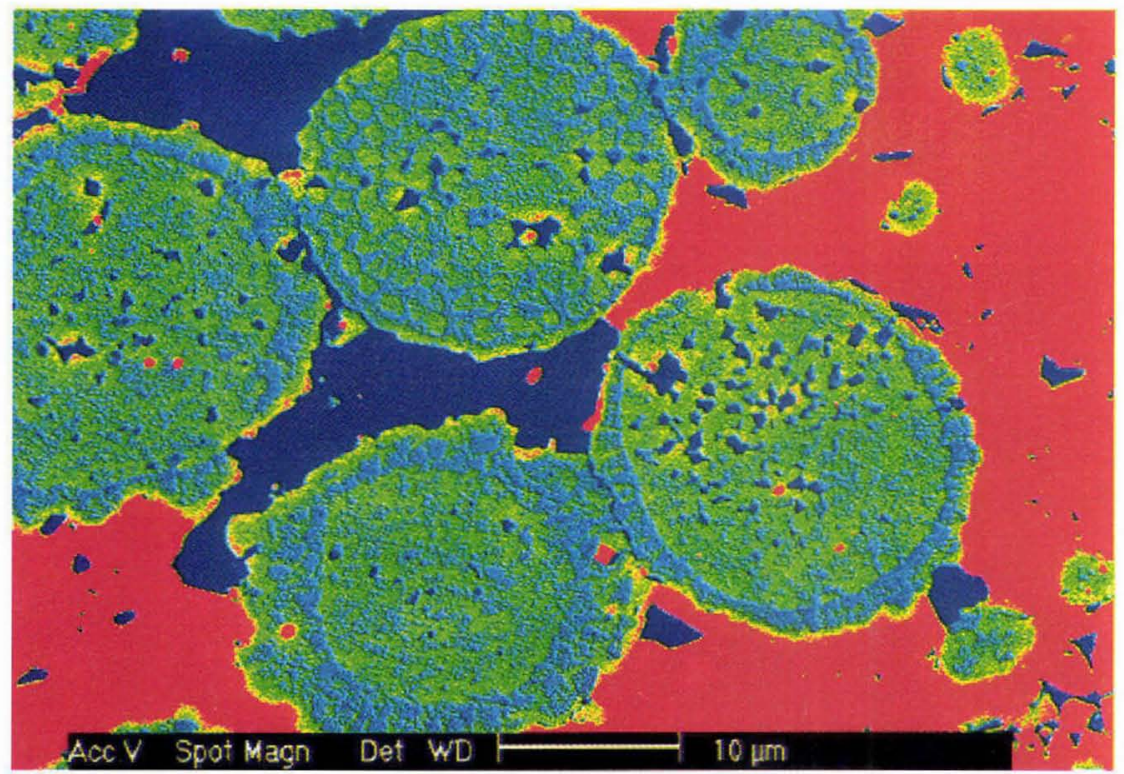

Fig. 3. False-colour scanning electron microscopy image showing pyrite framboids with secondary pyrite overgrowths. Green is pyrite, red is sphalerite and blue is carbonate gangue minerals.
The Middle Jurassic sandstones have a maximum thickness in excess of $650 \mathrm{~m}$ on eastern Traill $\varnothing$. The lower part of the succession is dominated by coarse-grained fluvial sandstones and conglomerates with thin coal seams and minor intervals of shales in which well developed root horizons occur. The upper part of the succession is generally more fine-grained and contains marine trace fossils and rare ammonites.

The Svinhufvud Bjerge region is cut by $\mathrm{N}-\mathrm{S}$ striking, eastwards dipping major faults which define a complex pattern of fault blocks. These fault blocks are cut by ENEWSW trending accommodation faults, and minor antithetic and synthetic faults. The major faults are characterised by an orange fault breccia; fragments of all rock types in the area, including the basic dykes, are present in the breccia embedded in a reddish matrix. This breccia preserves evidence for several slip events. The accommodation faults do not have any associated breccia, but exhibit a complex geometry of small fault blocks with well defined fault planes and drag folds. The minor synthetic and antithetic faults downthrow the Upper Jurassic Bernbjerg Formation with respect to the top of the Middle Jurassic sandstones, such that the Bernbjerg Formation is preserved below the basal Cretaceous unconformity. The minor faults are thus important for a structural understanding of the area and also appear to control the present location of sediments.

Lateral sedimentary changes and structural observations in Svinhufvud Bjerge show that the N-S trending faults have controlled basin evolution since at least mid-Jurassic times. This is shown by: (1) deposition of the Middle Jurassic sandstones that can be linked to movements on faults; (2) the downthrown Bernbjerg Formation which indicates that faulting along major faults and associated anti- thetic faults took place either during deposition of the Bernbjerg Formation or during uplift associated with the development of the basal Cretaceous unconformity; (3) the geometry of conglomeratic debris flow deposits within the Lower Cretaceous shales on the central fault block which indicates that minor movements took place along the major faults throughout the Early Cretaceous; (4) the character of the fault breccia which shows that the major faults suffered significant offset after intrusion of the Tertiary basic sills and dykes.

\section{Future work}

Material collected during the 1995 and earlier Survey expeditions to North Greenland will be compared with sample material from the Nanisivik and Polaris mineral deposits in Arctic Canada. Ore petrographic studies will be supplemented by lead isotope analyses at the Institute für Geowissenschaften und Lithosphärenforschung, JustusLiebig-Universität, Giessen, Germany. Sulphur isotope analytic work will be carried out at the Scottish Universities Research and Reactor Centre in Glasgow. Preliminary results from Peary Land show a very wide range of lead isotope signatures for galena samples, suggesting a variety of source rocks for the metals. The source of the sulphur and the temperature of the fluids from which sphalerite was precipitated will be determined by sulphur isotopic analyses, supplemented by fluid inclusion studies where applicable.

Field investigations will continue in both North and East Greenland in summer 1996. In North Greenland oregeological studies will be continued in central and eastern Peary Land and around Citronen Fjord, and a more detailed 


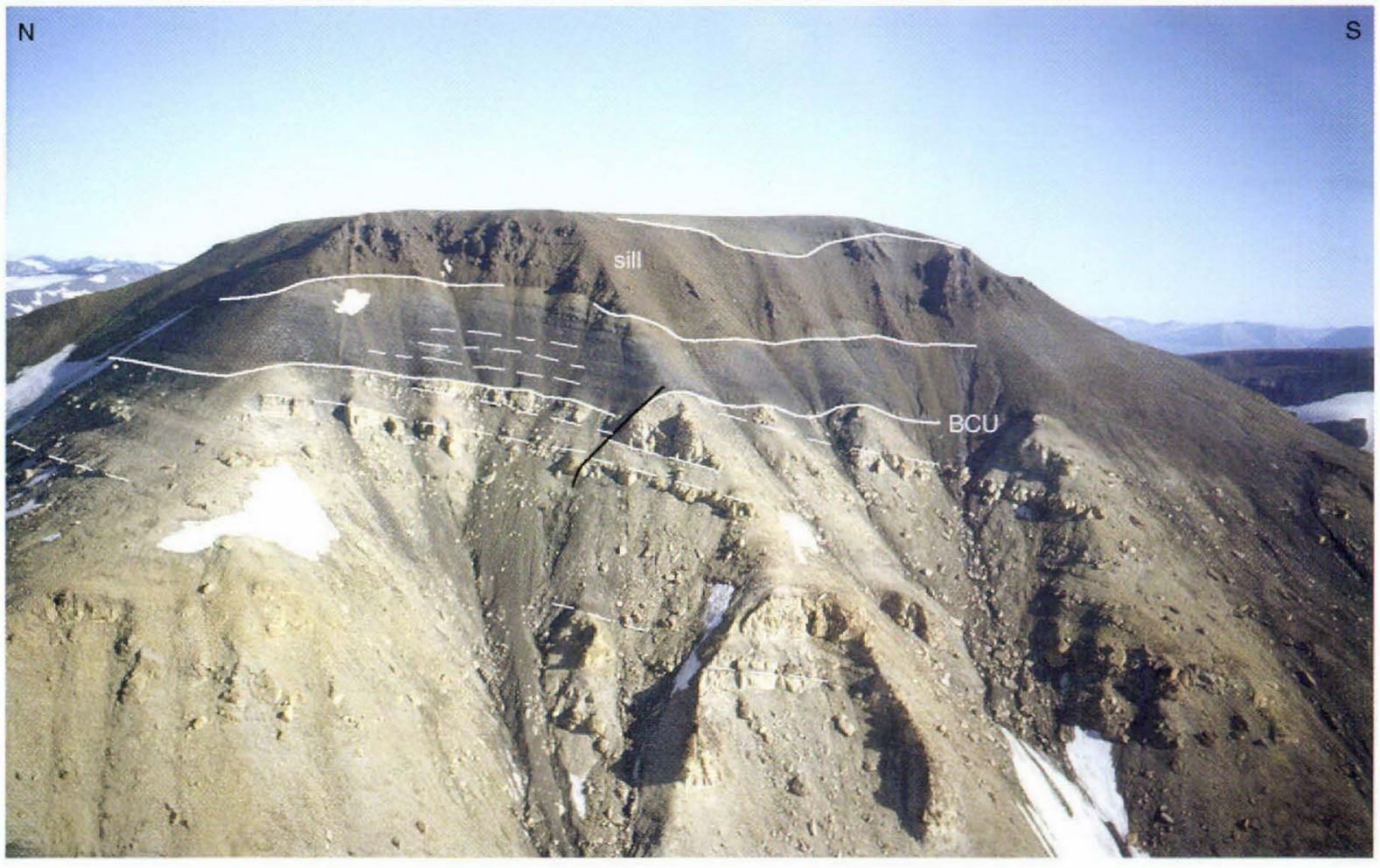

Fig. 4. Basal Cretaceous unconformity (BCU) seen from the west at Svinhufvud Bjerge, eastern Traill Ø. The southerly dipping Middle Jurassic sandstones are cut by the unconformity surface, which is overlain by Lower Cretaceous shales. Note post-Lower Cretaceous movements on the fault. The top of the mountain is a Tertiary sill complex.

combined ore-geological and sedimentological study will be carried out on Lower Palaeozoic platform carbonates in Wulff Land. Microbiological studies of the Citronen Fjord gossans will be continued.

In East Greenland field teams will study selected aspects of Upper Palaeozoic and Mesozoic geology in the region between northern Scoresby Land and Hold with Hope. The structural, sedimentological and diagenetic studies initiated in 1995 will be continued and supplemented by stratigraphic, sedimentological, diagenetic and ore-geological studies of primarily the Upper Permian, Triassic and Lower Cretaceous successions. The structural studies will be extended both north and south of Traill $\varnothing$, and older Carboniferous - Permian structures farther to the west will be included. The field based investigations will be supplemented by photogrammetric structural analyses on aerial photographs of central and eastern Traill $\varnothing$.

\section{References}

Higgins, A. K., Ineson, J. R., Peel, J. S., Surlyk, F. \& Sønderholm, M. 1991: Lower Palaeozoic Franklinian Basin of North Greenland. Bull. Grenlands geol. Unders. 160, 71-139.
Hurst, J. M. \& Surlyk, F. 1982: Stratigraphy of the Silurian turbidite sequence of North Greenland. Bull. Gronlands geol. Unders. 145, 121 pp.

Langdahl, B. R. 1995: Bakteriel oksidation af sulfidmineraler ved Citronen Fjord, Nordøst Grønland. Internal report, Danish Environmental Research Institute, 7 pp.

Paradis, S., Jonasson, I. R., Cheminant, G. M. \& Watkinson, D. H. 1988: Two zinc-rich chimneys from the plume site, southern Juan de Fuca Ridge. Can. Mineral. 26, 637-654.

Schønwandt, H. K. 1994: Mineral resource activities 1993. Spectrum of research and services. Rapp. Gronlands geol. Unders. $160,18-21$.

L. S., S. M. J., H. K. S., O. R. C., H. F., K. K. \& J. T., Geological Survey of Denmark and Greenland, Copenhagen

J. K., Geological Institute, University of Aarhus, DK-8000 Àrhus $C$

F. S., Geological Institute, University of Copenhagen, Øster Voldgade 10, DK-1350 Kobenhavn K

B. R. L., Afdeling for Mikrobiel Økologi, University of Aarhus, 